\title{
The metrics of Syrian physicians' brain drain to the United States
}

Brain drain phenomenon is defined as the large-scale emigration of a group of intellectuals and professionals with high qualifications and unique technical skills and knowledge. This phenomenon results in significant socioeconomic consequences as a result of the continuous loss of practitioners and trainees as well as losing their social value and financial support to their country of origin. Many countries suffered from brain drain to variable extents particularly during the second half of the $20^{\text {th }}$ century, following World War II. In contrast, many countries have markedly gained form this movement leading to remarkable development of their economy and educational systems due to the significant contributions made by the immigrating professionals to their respective fields.

Physicians' brain drain had a substantial burden on developing countries over the past few decades due to the significant loss of medical professionals and health care providers in both clinical care and medical education fields. For example, the number of international medical graduates (IMGs) in the United States is estimated at 245,000 according the American Medical Association (AMA) statistics in 2007, representing an approximately $25 \%$ of the entire health workforce in the nation ${ }^{[1,2]}$ where physicians immigrating from lower income countries constitute $60 \%$ of all practicing IMGs. India occupies the first rank among the source countries of IMGs in the United States with an emigration factor of $10.6 \%$. (Emigration factor is defined as the number of physicians from a source nation practicing in a recipient country divided by the total number of physicians practicing in the source country. $)^{[1,2]}$ This is followed by a number of countries such as Philippines, Pakistan, and some Latin America and Middle East countries such as Egypt, Syria, and Lebanon. ${ }^{[1,2]}$ Between 2004 and 2008, the data from the AMA records indicated that the total numbers of Syrian physicians practicing in the United States has increased from approximately 3200 to 3900 representing $0.4 \%$ of the

\begin{tabular}{|l|l|}
\hline \multicolumn{2}{|c|}{ Access this article online } \\
\hline Quick Response Code: & Website: \\
\hline & www.avicennajmed.com \\
\cline { 2 - 2 } & \\
\hline
\end{tabular}

health workforce and 1.6\% of IMGs. ${ }^{[1,2]}$ The Global Health Observatory data repository reported that the total number of physicians in Syria was estimated at 31,000, according to the 2008 statistics, with an approximately 15 physicians per 10,000 capita. ${ }^{[3]}$ This renders the emigration factor of Syrian physicians to the United States to be around $13 \%$. A study published in Health Policy in 2007 analyzed the dynamics of international immigration patterns of physicians to the United States and found that Syria has a higherthan-expected physicians immigration rates. ${ }^{[4]}$ In fact, Syria was the sixth country among the top eight countries which have a higher-than-expected rate and the second Arab country after Lebanon when adjusting for the population size. ${ }^{[4,5]}$ Recently, the Educational Commission for Foreign Medical Graduates (ECFMG) indicated in its 2010 annual report that a total of 140 certificates were issued to medical students who graduated from Syrian medical schools representing $1.5 \%$ of the total certificates issued in 2010 . Also, a total of 240 exchange visiting student visas were issued for Syrian medical graduates in the 2009-2010 academic year. ${ }^{[6]}$

This data, summarized in Table 1, indicates the latitude of the physicians' brain drain from Syria, especially when taking into consideration the number of Syrian physicians immigrating to other geographic regions other than United States such as Europe and Arab Gulf countries.

Major factors contribute to this trend on physicians' immigration from Syria including the large differences in incomes and standards of living, the scarcity and instability of professional and academic opportunities, and the "culture of emigration" among physicians in training. The majority of the recipient countries provide a proper professional

\begin{tabular}{|c|c|}
\hline $\begin{array}{l}\text { Table I: Summary of the met } \\
\text { brain drain to the United Stat }\end{array}$ & ians' \\
\hline $\begin{array}{l}\text { Total number of physicians in Syria } \\
(2008)\end{array}$ & 31,000 \\
\hline $\begin{array}{l}\text { Number of Syrian physicians in the } \\
\text { United States (2008) }\end{array}$ & $\begin{array}{l}3900 ; 0.4 \% \text { of US health } \\
\text { workforce; I.6\% of IMGs in } \\
\text { the United States }\end{array}$ \\
\hline Emigration factor to the United States & $13 \%$ \\
\hline $\begin{array}{l}\text { Syria's rank among IMGs in the } \\
\text { United States }\end{array}$ & 16 \\
\hline $\begin{array}{l}\text { ECFMG Certificates issued to Syrian } \\
\text { medical graduates } 2010\end{array}$ & $\begin{array}{l}\text { I } 40 \text { (I.5\% of all ECFMG } \\
\text { certificates) }\end{array}$ \\
\hline $\begin{array}{l}\text { Exchange visiting student visas issued } \\
\text { in } 2009-2010\end{array}$ & 240 \\
\hline
\end{tabular}


atmosphere, better academic freedom, and flexibility with much better overall living conditions. Unfortunately, some of these factors are difficult to counteract in a short-term intervention. Nevertheless, several measures can be done to increase the retention of practicing and graduating physicians or minimize the effect of brain drain on the health and medical education systems. Core modifications in health and education policy and professional atmosphere are essential to achieve broad societal changes and to reduce the rates of physicians' emigration. Providing better academic and professional opportunities, allowing more flexibility to the health and education systems, promoting research and its infrastructure, establishing networks between professionals inside and outside the country, as well as encouraging the return of the emigrant physicians will minimize the effects of physicians' brain drain which will ultimately improve the overall rating of the Syrian health and medical education systems.

Mohammad Arabi, Abdul Ghani Sankri-Tarbichi' ${ }^{1}$

University of Michigan Health System, Ann Arbor, MI, ${ }^{1}$ Detroit Medical Center, Wayne State University, Detroit, MI, USA E-mail:marabi@med.umich.edu

\section{REFERENCES}

1. Mullan F. The metrics of the physician brain drain. N Engl J Med 2005;353:1810-8.

2. International medical graduates in American medicine: Contemporary challenges and opportunities. January 2010. Available from: http://www. ama-assn.org/ama1/pub/upload/mm/18/img-workforce-paper.pdf. [Last Accessed on 2011 Dec 18].

3. Global Health Observatory Data Repository: Syrian Arab Republic Country statistics. Available from: http://apps.who.int/ghodata/?vid= 19200andtheme $=$ country. [Last Accessed on 2011 Dec 18].

4. Hussey PS. International migration patterns of physicians to the United States: A cross-national panel analysis. Health Policy 2007;84:298-307.

5. Akl EA, Maroun N, Major S, Chahoud B, Schünemann HJ. Graduates of Lebanese medical schools in the United States: An observational study of international migration of physicians. BMC Health Serv Res 2007;7:49.

6. Educational Commission for Foreign Medical Graduates 2010 ANNUAL REPORT. Available from: http://www.ecfmg.org/resources/ECFMG-2010annual-report.pdf. [Last Accessed on 2011 Dec 18].

Cite this article as: Arabi M, Sankri-Tarbichi AG. The metrics of Syrian physicians' brain drain to the United States. Avicenna J Med 2012;2:1-2.

Announcement

\section{“QUICK RESPONSE CODE” LINK FOR FULL TEXT ARTICLES}

The journal issue has a unique new feature for reaching to the journal's website without typing a single letter. Each article on its first page has a "Quick Response Code". Using any mobile or other hand-held device with camera and GPRS/other internet source, one can reach to the full text of that particular article on the journal's website. Start a QR-code reading software (see list of free applications from http://tinyurl.com/yzlh2tc) and point the camera to the QR-code printed in the journal. It will automatically take you to the HTML full text of that article. One can also use a desktop or laptop with web camera for similar functionality. See http://tinyurl.com/2bw7fn3 or http://tinyurl.com/3ysr3me for the free applications. 